\title{
Teaching in a Summer School Program as Practicum: Challenges and Implications
}

\author{
Chin-Wen Chien \\ National Hsinchu University of Education, Hsinchu City, Taiwan
}

\begin{abstract}
This study focuses on the implementation of a summer school program as prospective teachers' English Language Learner (ELL) endorsement practicum in the northwest United States. The participants are three prospective teachers and the data includes interviews, documents, and classroom observations. The four major findings are: students teachers' engagement with a limited ranges of teaching styles, little collaboration between cooperating and prospective teachers, the unclear goals of the summer school, and also curriculum planning and adaption. Four suggestions are provided regarding effectively implementing a summer school for practicum.
\end{abstract}

Index Terms - cooperating teacher, endorsement, English language learner (ELL), summer school, practicum, prospective teachers

\section{INTRODUCTION}

This study examines a summer school program in 2010 that was designed and provided for English Language Learner (ELL) with the aim of bridging the achievement gap between ELLs and their English-speaking peers. Prospective teachers taught in this summer school program to gain their ELL endorsement practicum. An ELL endorsement program gives teacher candidates a foundation in second language acquisition theory, linguistics, language teaching methods, and cultural issues related to teaching a diverse student population, whilst a practicum provides teacher candidates with hands-on experience utilizing the latest instructional methods.

The participants in this study were three prospective teachers who completed their elementary school teacher certification and did their student teaching in the academic year 2009 in the United States northwest. The data in this study includes interviews, documents, and classroom observations and aims to discuss the following questions. First, how was the practicum arranged in the summer school? Second, what teaching activities were the prospective teachers involved in and what did they learn from their participation? Third, what challenges and problems did the prospective teachers face in doing this practicum? In the conclusion of this study some suggestions are provided regarding effectively implementing a summer school for practicum.

\section{LITERATURE REVIEW}

The literature review discusses the teaching practicum in terms of its importance, problems, suggestions, and implementation. There are a variety of terms related to practicum, such as practice teaching, field experience, apprenticeship, practical experience, and internship (Crooks, 2003; Gebhard, 2009). Zeichner (1990) defines a practicum as including "all varieties of observation and teaching experiences in a pre-service teacher education program."

Freeman (1989) identifies four key components required in a practicum for language teaching: knowledge, skills, attitude, and awareness. Knowledge should include subject matter (the "what" of teaching), characteristics of the learner (the "who"), and the learning environment (the "where"). Skills include the ability to select methods, use techniques, manage a classroom, and so forth. Attitudes meanwhile, is defined as "the stance one adopts toward oneself, the activity of teaching, and the learner one engages in the teaching/learning process" (p. 33). Awareness refers to "the capacity to recognize and monitor the attention one is giving or has given something" (p.33).

Through a practicum, pre-service teachers can gain practical classroom teaching experience, apply theory and teaching ideas from previous course work, and learn by observing experienced teachers. They also can enhance lesson-planning skills, gain skills in selecting, adapting, and developing original course materials, and expand their awareness of how to set their own goals related to improving their teaching. Moreover, they can question, articulate, and reflect on their own teaching and learning philosophies as well as see their own teaching through different lenses, learn how to make their own informed teaching decisions through systematic observation, and explore their own and others' teaching (Richards \& Crookes, 1998; Crooks, 2003).

Mentor or collaborating teachers play an important role in prospective or student teachers' practicum. Pak's (2005) study focused on the factors affecting the relationship between a mentor teacher and a student teacher, concluding that there are four major influences: the experiences and personal dispositions of the subjects, the school culture, the student teacher's university teacher preparation program, and the student teaching classroom placement. Pak calls for better 
selection and training in regard to mentors.

Tomas, Rai, and Haslam (2008) recognize that interactions between the collaborating teacher and supervisors as well as between pre-service teachers are missing in most practicum. They point out that while the supervisors select the cooperating teacher, they have no control over the quality of training that the pre-service teachers will receive in their schools. Supervisors can provide only limited feedback and support to pre-service teachers in terms of their teaching in the real classrooms. They also point out that pre-service teachers do not have many opportunities to observe other pre-service teachers' instruction.

Janopoulos' (1991) study examines the objectives of the practicum offered in the master's degree program for teachers of English to speakers of other languages (MATESOL) throughout the United States. Although Janopoulos' study focuses on MATESOL, the findings can be applied to practicum in ELL endorsement programs. He concludes that practicum objectives should be based as much on student needs as on program philosophy. The objectives should be seen as a dynamic, ongoing process in which goals may change from semester to semester and from student to student.

The above studies focus on the MATESOL practicum or practicum in general. This study aims to study the practicum of an ELL endorsement program, particularly the potential and problems of using summer school as practicum for an ELL endorsement program. This study aims to provide suggestions and implications on how summer school can be used for practicum for teacher education.

\section{METHOD}

The major data in this study include classroom observations, interviews, and documentation. The first type of data, documents, are the elicitation of themes or content in a body of written or visual media (Hammersley \& Atkinson, 1983; LeCompte \& Schensul, 1999). Here, copies were taken of the summer school program and handouts.

Semi-structured interviews were used in order to explore issues, probe for and follow up on the responses and to allow for interaction (Blaikie, 2000; Flick, 1998; Hitchcock \& Huges, 1989). An interview protocol was used in this study. The interviews were conducted on the last week of the practicum and lasted between thirty minutes and an hour. The interviews aimed to find out the participants' education and language background, their teaching philosophies, and their challenges and concerns regarding the summer school program.

Observation is the most natural of all ways of collecting data, because it allows researchers to gain a better understanding of various behaviors (Bartels, 2005; Richards \& Morse, 2007). Seven classroom observations were conducted for this study: three for Phoebe's class, one for John's class, and three for Yolanda's class. The researcher analyzed the data by organizing it into more abstract units of information or themes (Creswell, 2009; Hatch 2006; LeCompte \& Schensul, 1999; Marshall \& Rossman, 2006).

The participants in this study were three prospective teachers who completed their elementary school teacher certification and did their student teaching in the academic year 2009. The three of them did their practicum in summer in order to gain an ELL endorsement certification offered by a university in the Northwest. Details about the participants are show in Table 1 below.

TABLE 1

DEMOGRAPHICS OF PARTICIPANTS

\begin{tabular}{|l|l|l|l|}
\hline & Yolanda & Phoebe & John \\
\hline Education & M.A. in education & B.A. in Sociology & $\begin{array}{l}\text { B.A. in Sociology, } \\
\text { Special education }\end{array}$ \\
\hline Prior work experience & $\begin{array}{l}\text { Student teaching } \\
\text { Part-time ELL teacher }\end{array}$ & Literacy tutor & Student teaching \\
\hline Languages & English, Korean & English, Spanish & English, Spanish \\
\hline Grade level & First grade & Third & Second grade \\
\hline
\end{tabular}

\section{RESULTS}

The analysis focuses on the practicum arrangement, teaching activities, teachers' learning, and challenges and problems.

\section{A. Practicum Arrangement}

The prospective teachers were required to complete a 36-hour practicum consisting of six hours of observation and thirty hours comprising co-teaching with a cooperating teacher or solo teaching. The teachers also had to submit two video-recorded lessons, lesson plans, and post-lesson reflections to the practicum supervisor. The teachers were paired with an ESL-endorsed cooperating teacher based on their grade level preference. Unfortunately, there were a limited number of classes at each grade level in the summer school with only one class each for K-1 and first through fourth grades.

\section{B. Teaching Activities}

While Yolanda and John were involved in station teaching in their practicum, Phoebe shared the instruction with her 
cooperating teacher. In Yolanda's class, four stations were arranged with a different instructional focus: sight words, phonics, reading comprehension, and the alphabet. Yolanda was responsible for phonics instruction. She had specific procedures on teaching phonics in Example 1. She first showed the alphabet card and asked students to sound it out. She used flashcards to teach different words that began with that letter. She gave students white boards whereby she would say a word and students had to draw a picture and write the word. She then asked students to sound out the word again before asking them to spell it out. Finally, she asked students the first sound, the second sound, or the third sound of that word.

Example 1

Yolanda: (Shows the flashcard " $\mathrm{k}$ to Ss) How do you pronounce this?

S1: [k]

Yolanda: If I show you $\mathrm{k}_{-}$, what words begin with that sound?

S1: Kite.

S2: Key.

...

Yolanda: I will give you the board. Can you draw the "kite" and write the "kite"?

Ss: (Draw the kite and write kite)

Yolanda: (Point to k-i-t-e) [k]-[ al ]-[t]. Let's sound it one more time. [k]-[ al ]-[t].

Yolanda: How do you spell "kite"?

Ss: K-I-T-E.

Yolanda: Good job!

Yolanda: What is the first sound?

Ss: [k]

Yolanda: What is the second sound?

Ss: [al ]

Yolanda: What is the third sound?

Ss: [t].

Yolanda: When you put them together, you say...

Ss: [kal t]

Yolanda: Good job! Now erase it.

There were only three stations in John's class; they covered phonics and alphabet instruction, songs and chants, and reading comprehension. John was responsible for teaching the students phonics and the letters of the alphabet. Similar to Yolanda, John taught the phonics in a certain procedure as in Example 2. In this example, he first reviewed the letters taught in the previous lesson. He taught a new letter " $\mathrm{m}$ " and asked students to pronounce the letter's sound. He said a word and asked students to repeat after him. He later said a word and students had to write the letter of the first or the last sound of the word. He also taught students the concept of rhyming words.

Example 2: John's Phonics Instruction

John: What does $\mathrm{S}$ make?

Ss: [s]

(Use the pointer to point to the letter Tt) What's this letter?

Ss: $\mathrm{Tt}$

John: Today we will learn a new letter Mm. Repeat the word after me, [m].

Ss: $[\mathrm{m}]$

$\cdots$

John: I say the word and you say it back to me. Mouse

Ss: Mouse

$\cdots$

John: (Give students white boards) Next word I would you like to hear "set." What is the first sound you hear?

Ss: (Write "s" on the white board) [s].

John: Do you all agree [s] is the first sound you hear from the word "set"?

Ss: Yes

Mr. James: What is the third sound you hear from "set"?

Ss: [t]

John: "Sam" and "ham" have the same rhyme. What does "rhyme" mean?

Ss: (No response)

S1: What is "rhyme"?

John: Rhyme means two words have the same sound in them like "Sam" and "ham." Do they have the same sound? Ss: Yes. 
John: Next word is "at."

Ss: (Write "at" on the white board)

John: Next word is "sat." Think about what you have to change.

Ss: (Write "sat" on the white board)

John: Next word is "mat."

Ss: (Write "mat" on the white board).

John: Try "cat."

Ss: (Write "cat" on the white board)

In station teaching, Phoebe did mini-lessons and provided students with individual practice. Phoebe liked station teaching, saying "The students were most engaged; enthusiastic also the best results occurred." Although station teaching was fun and interactive, Yolanda hoped that she could see how the cooperating teacher did the whole class instruction.

Phoebe shared the teaching with her cooperating teacher in task-based, writing, and reading. For the task-based activities, on July 19, 2010, the students made a community poster by cutting pictures from magazines and writing captions on the bottom of the pictures. On July 20 and 21, the students were divided into two groups and Phoebe worked with one group. The students made their own paper puppets, read through the lines, and put on a puppet show based on a book they had read recently. In terms of writing activities, students were given ten minutes free writing on topics such as 'my family members'. While students did free writing, Phoebe worked around the classroom and helped them if needed.

The whole class was divided into two teams and Phoebe did the reading circle in Example 3. Phoebe pointed to the author's name on the cover first. She then led students to read aloud and paused to ask students the meaning of the word nature. One student replied "Everything around." Phoebe asked the rest of the students to add more. One student answered "trees" and one student said "animals." Phoebe summarized what students said at the end.

Example 3: Phoebe's reading circle

Phoebe: The author is Douglas Gloria. Let's look at it together.

Phoebe: Let's read it together.

Phoebe and Ss: (Read aloud)

Phoebe: What is nature?

S: Everything around

Phoebe: What else can you add?

S: Trees

S: Animals

Phoebe: Things around us that are outside. The grass, trees, birds, animals, things that are outside and around us are in the nature.

S: I know that.

S: It's moving. (Hands wave)

\section{Prospective Teachers' Learning}

The biggest takeaway from doing practicum in the summer school for these prospective teachers was their learning about teaching strategies from their instructors and cooperating teachers.

With regard to teaching strategies, Phoebe realized the benefits of giving explicit instruction, use of building language frames, and modeling writing. John did not take any assessment class in the elementary school teacher education program (TEP), so he loved the assessment class. He felt that he had never learned how to do assessment before this assessment class.

Prospective teachers learned from the instructors. Yolanda particularly mentioned that one instructor encouraged them to try new things as "Dr. Caitlin was great. She really motivated us to try new things and made it seem like it was doable. She said it would be hard and we would make mistakes, but it would be possible."

Prospective teachers also learned a lot from their cooperating teachers. Yolanda's cooperating teacher made the point clear that teachers should make the effort to build connections with ELLs' family and parents. Yolanda worked hard on what her cooperating teacher emphasized and she reminded the parents that they were on the same team in regard to the students' learning. Phoebe learned a lot about teaching strategies from her cooperating teacher, such as table talk, visuals, talking, and partner work. John particularly learned more GLAD strategies implemented by his cooperating teacher.

\section{Challenges and Problems}

These prospective teachers faced three major challenges and problems while doing practicum in summer school. The first issue was the pairing of the prospective teachers with their master teachers. Phoebe highlighted that cooperating teachers should be master teachers and that the practices they use align with those of the endorsement program. John had a different teaching philosophy and style from his cooperating teacher and saw his cooperating teacher as being too concerned with order and little details. Neither John nor Yolanda experienced any collaboration with their cooperating teachers, or any clear discussion about teaching objectives. 
The second major problem was the whole set-up of doing practicum in the summer school. John was not sure about the objectives of the summer school and he said,

"I would like to have had a little more clarity around the information and end goals of the summer program. I wish there was a clear connection between the university and summer school. It was not clear what I was supposed to be doing."

Furthermore, the prospective teachers had also hoped they could see the students' profiles. Yolanda said "I would love to have had more background information on the students. We did not know anything about some of these kids."

The third major issue was regarding the curriculum used in the summer school as the prospective teachers felt it was inappropriate to use content lower than the students' actual grade levels. Although the inappropriate curriculum seemed to be a weakness, the teachers did learn how to adapt it to meet their students' needs and proficiency levels.

\section{DiSCUSSION AND IMPLICATIONS}

Based on the data analysis, four issues are investigated relating to the implementation of a summer school program as prospective teachers' ELL endorsement: the prospective teachers' involvement in and experience of different teaching styles, collaboration between collaborating and prospective teachers, the goals of the summer school, and curriculum planning and adaption.

\section{A. Involvement in and Experience of Teaching Styles}

In this study, Phoebe shared the instruction with her cooperating teacher. However, Yolanda and John were involved in only one type of teaching style, "station teaching" in their practicum. They never saw how their collaborating teacher carried out whole class instruction, and it should also be noted that having more than one teacher or adult in the classroom is not common in most elementary school settings. "Utilize cooperative learning experiences for ELLs" is one of the six critical topics that should be included in ELL teacher education (Wassel, 2009); therefore, these prospective teachers should have been exposed to how a teacher can incorporate different types of classroom activities in their classroom such as whole class instruction, group work, pair work, cooperative learning, individual work, etc.

Phoebe also hoped that collaborating teachers should be highly-experienced teachers, preferably ELL-endorsed. Freeman (2002) suggests that well-crafted mentoring programs should play a critical role in the design of teacher education programs. Freeman and Johnson (1998) also suggest that teacher education practices in TESOL should include experienced teachers as mentors to novices during field experiences or school-based programs. Teachers always benefit from each other's classes and they can use the opportunity of being observed to become more aware of their own teaching. By doing so, the pedagogies observed will imply a different understanding of the professional process of learning to teach. Therefore, assigning an experienced English-endorsed teacher as a mentor to the prospective teacher should be mandated in the practicum.

\section{B. Collaboration between Cooperating and Prospective Teachers}

The three participants in this study did not have many chances to collaborate with their cooperating teachers, despite their expectations. Such collaboration should be fostered such means as through working together on lesson planning or curriculum development. They can identify goals for a lesson and content area they want to work on together and may spend time collaboratively discussing and designing lessons which they then teach while others observe. The teachers can next meet to discuss their observations and ideas on how to improve the lesson (Wiburg \& Brown, 2007). A complex relationship exists among teachers, new materials, teaching practices, and peers. Teachers can construct themselves as pedagogical and curricular leaders among their peers (Leander \& Osborne, 2008).

Another way that prospective and cooperating teachers can collaborate is through collaborative dialogue as this process gives them multiple perspectives in problem solving and in issues of concern (Bailey, 1996; Howelett, 2004). Bartlett (1990) also claims that teaching is an interactive process, so teachers need to develop shared understandings in a community of knowledge users and developers.

\section{The Goals of the Summer School}

The university practicum supervisor provided practicum guidelines for all prospective teachers at the summer school; they included a practicum requirement checklist, observation guidelines, ELL endorsement practicum reporting form, observation worksheet, observation report guidelines, observation report evaluation form, lesson guidelines, lesson plan sample format, and an evaluation and post-lesson reflection rubric. The prospective teachers faced challenges and problems when they did their practicum in summer school as firstly, they did not have much knowledge about the students' backgrounds, academic achievement or test data. Secondly, because they did not know the major goals of the summer school they did not know how to best scaffold the ELLs' learning.

Orientation and professional development should be provided for teachers before the summer school begins. Topics covered should include the goals of the summer school, curriculum, standards, and ELL teaching strategies, so teachers will be familiar with how they should teach in order to meet the objectives. Second, students' data including academic performance, English proficiency levels, educational background in home country, etc should be provided, so teachers have a better understanding of students' background. A pre-assessment and post-assessment should be provided to 
check if the summer school instruction does in fact positively influence student academic performance and to determine what further instruction can be provided.

\section{Curriculum Planning and Adaption}

The curriculum used in the summer school was at a lower level than the students' actual grade level. Although the three prospective teachers thought this inappropriate curriculum was a major issue in the practicum, they nevertheless used this as a chance to learn how to modify and adapt the curriculum to best fit their students' needs. Curriculum and lesson planning is crucial in language teaching. Lesson planning can provide opportunities for teachers' professional growth and learning, whether individually or collectively and the process also acts to demonstrate teachers' expertise. Teacher self-actualization, motivation, and sense of achievement are integral to successful curriculum and lesson planning decision-making (Marshall, Day, Hannay, \& McCutcheon, 1990).

\section{CONCLUSION}

This study focused on the implementation of a summer school program as prospective teachers' ELL endorsement practicum in the northwest United States. The four major findings are: students teachers' engagement with a limited ranges of teaching styles, little collaboration between cooperating and prospective teachers, the unclear goals of the summer school, and also curriculum planning and adaption. In order to make teaching in summer school a useful practicum for ELL teachers, universities and elementary schools should collaborate to find master teachers' as cooperating teachers, encourage collaboration between cooperating and prospective teachers, provide a practicum orientation to prospective teachers, and equip prospective teachers with expertise and skills in curriculum designs and adaptation.

\section{REFERENCES}

[1] Blaikie, N. (2000). Designing social research. Cambridge: Polity Press.

[2] Bartlett, L. (1990). Teacher development through reflective teaching. In J. C. Richards \& D. Nunan (Eds.), Second language teacher education. Cambridge, UK: Cambridge University Press, 202-214.

[3] Bartels, N. (2005). Researching applied linguistics in language teacher education. In Bartels, N. (Ed.). Applied linguistics and language teacher education. New York: Springer Science and Business Media, Inc.

[4] Bailey, F. (1996). The role of collaborative dialogue in teacher education. In D. Freeman \& J. C. Richards (Eds.), Teacher learning in language teaching. New York: Cambridge University Press, 260-280.

[5] Creswell, J. W. (2009). Research design: Qualitative, quantitative, and mixed methods approach ( $3^{\text {rd }}$ ed.). Thousand Oaks: Sage Publications.

[6] Crookes, G. (2003). A practicum in TESOL. Cambridge: Cambridge University Press.

[7] Flick, U. (1998). An introduction to qualitative research. Thousand Oaks: Sage Publications.

[8] Freeman, D. (1989). Teacher training, development, and decision making. A model of teaching and related strategies for language teacher education. TESOL Quarterly 23.1, 27-45.

[9] Freeman, D. (2002). The hidden side of the work: Teacher knowledge and learning to teach. A perspective from North American educational research on teacher education in English language teaching. Language teaching 35. 1, 1-13.

[10] Freeman, D., \& Johnson, K. E. (1998). Reconceptualizing the knowledge-base of language teacher education. TESOL Quarterly 32.3, 397-417.

[11] Gebhard, J. (2005). The practicum. In A. Burns. \& J. C. Richards. (2009) (Eds.), The Cambridge guide to second language teacher education. New York: Cambridge University Press, 250-258.

[12] Hammersley, M., \& Atkinson, P. (1983). Ethnography. Principles in practice. New York: Humanities Press.

[13] Hatch, J. A. (2002). Doing qualitative research in education settings. Albany: State University of New York Press.

[14] Hitchcook, G., \& Hughes, D. (1989). Research and the teacher: A qualitative introduction to school-based research. New York: Humanities Press.

[15] Howelett, K. M. (2005). The impact of an English as a second language professional development program on teacher practice. $\mathrm{Ph}$. D. dissertation, University of Arkansas, Arkansas.

[16] Janopoulos, M. (1991). TESOL practicum: Bridging the gap between student needs and program objectives. Ph. D. dissertation, University of Northern Iowa, Iowa.

[17] Leander, K. M., \& Osborne, M. D. (2008). Complex positioning: Teachers as agents of curricular and pedagogical reform. Journal of Curriculum Studies, 40. 1, 23-46.

[18] LeCompte, M. D., \& Schensul, J. J. (1999). Designing and conducting ethnographic research. Walnut Creek: AltaMira.

[19] Marsh, C., Day, C., Hannay, L., \& McCutcheon, G. (1990). Reconceptualizing school-based curriculum development. London: The Falmer Press.

[20] Marshall, C., \& Rossman, G. B. (2006). Design qualitative research (4 ${ }^{\text {th }}$ ed.). Thousand Oaks: Sage Publications.

[21] Pak, M. (2005). Learning to teach in urban school: Influences affecting mentor teacher-student relationship. Ph. D. dissertation, University of California, Los Angeles.

[22] Richards, J. C., \& Crookes, G. (1988). The practicum in TESOL. TESOL Quarterly, 22.1, 9-27.

[23] Richards, L., \& Morse, J. M. (2007). Readme first for a user's guide to qualitative methods. Thousand Oaks: Sage Publications.

[24] Tomas, Z., Rai, F., \& Haslam, M. (2008). Designing and implementing the TESOL teaching practicum abroad: Focus on interaction. TESOL Quarterly, 42. 4, 660-664.

[25] Wassel, E. (2009). Exploring professional development needs of teachers for teaching English second language learners: A mixed methods study in a homogenous white county. Ph. D. dissertation, Widener University, Pennsylvania. 
[26] Wiburg, K. M., \& Brown, S. (2007). Translating lesson study from Japan to the United States. In K. M. Wiburg \& S. Brown. (Eds.), Lesson study communities increasing achievement with diverse students. Thousand Oaks: Corwin Press, 1-17.

[27] Zeichner, K. (1990). Changing directions in the practicum: Looking ahead to the 1990s. Journal of Education for Teaching, 16. $2,105-132$

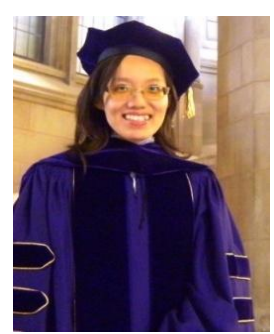

Chin-Wen Chien received her Doctor of Education degree in Curriculum and Education, from the University of Washington, Seattle, Washington, the United States, in 2011. Her dissertation focuses on the influence of language teacher's professional development on their classroom practice.

She is an assistant professor in Department of English Instruction of National Hsinchu University of Education in Taiwan. Her research interests include language education, language teacher education, and curriculum and instruction.

Dr. Chin-Wen Chin is a member of Teaching English to Speakers of Other Languages (TESOL) and English Teaching Association, R.O.C. 